\title{
PETROGRAPHY AND PROVENANCE OF SANDSTONE AND STUDIES OF SHALE OF KULDANA FORMATION, KALAMULA AND KHURSHEEDABAD AREA, KAHUTA, AZAD KASHMIR
}

\author{
*Ahmer Bilal' ${ }^{1}$, Muhammad Sabir Khan ${ }^{1}$ \\ ${ }^{1}$ Institute of Geology, University of Azad Jammu and Kashmir, Muzaffarabad, 13100, \\ Pakistan. *Corresponding author: ahmerbilal47@gmail.com
}

This is an open access article distributed under the Creative Commons Attribution License, which permits unrestricted use, distribution, and reproduction in any medium, provided the original work is properly cited

\section{ARTICLE DETAILS}

\section{Article history:}

Received 24 October 2016

Accepted 7 December 2016

Available online 3 January 2017

Keywords:

Hazara Kashmir Syntaxis

Neogene rocks Vergent

Trending

\section{ABSTRACT}

Rocks exposed in the study area are Kuldana Formation which is comprised of variegated color shale and sandstone. The model data of Kuldana sandstone exhibit average quartz 35\%, feldspars 3\%, rock fragments $20 \%$ and heavy minerals. The quartz grains are of igneous and metamorphic origin. Mineral quartz, feldspar, and rock fragments in the sandstone suggested an acidic plutonic and metamorphic provenance. Rock fragments are of sedimentary, volcanic and metamorphic rocks. The sedimentary grains include limestone, dolomite, quartzite, sandstone and siltstone. The volcanic rock fragments are of fine grained basalts. The metamorphic rock fragments are of slates and schists.

Heavy minerals include tourmaline, zircon, garnet, epidote, sphene and apatite. Hematite and calcite are the dominating cementing material with minor chlorite. The sandstone is classified as graywacke. The low modal proportion of quartz and high content of rock fragments indicates low degree of mineralogical maturity of the sandstone. The poor degree of sorting, angular to sub-angular framework constituents and abundance of matrix suggested that sandstone is texturally immature. The sutured quartz grains contacts, alteration of plagioclase to clay minerals and deformed muscovite indicate diagenetic changes in the sandstone at depth under pressure.

The XRD analysis of shale show minerals chlorite thuringite, orthoclase, corrensite mica, illite, albite smectite, saponite, montmorillonite, goethite, kaolinite, vermiculite, aragonite, calcite, quartz, siderite, muscovite, hematite, pyrite and dolomite. Recalculated value of quartz, clay and carbonates on ternary diagram shows that the clays are argillaceous. Quartz, orthoclase, albite and muscovite in the shale suggest acidic plutonic and metamorphic provenance.

\section{Introduction}

Himalayas are cretaceous aged mountain belts formed by collision between Eurasian and Indian plate. These mountain belts of Himalayas are subdivided by Ganssar (1964). Our study area is bounded by MBT on Western side and PT on East (Fig. 1). These rocks are exposed in the Kalamula and Khursheedabad area (Fig. 2). It is a highly deformed fold and thrust belt. The rock units exposed in this area are mainly comprised of the sandstone and shales of Kuldana Formation which is medium to fine grained sandstone of Eocene age.

\section{Regional Tectonic and Geological Settings}

The mountain belt of Himalayas is formed due to collision of Eurasian and Indian plates (Kazmi and Jan, 1997). The collision between the two huge continental blocks intensely deformed Phanerozoic sediments. The grade of regional metamorphism, magmatic episodes and intensity of deformation increased towards collisional zone. Himalayas are comprised of igneous, metamorphic, meta-sedimentary and sedimentary rocks. Proterozoic basement rocks are exposed in Besham, Nanga Parbat Haramosh, Upper Kaghan and Neelum Valley in north western margin of the Indian Plate. The basement rocks are regionally metamorphosed and intruded by granite plutons (Kazmi and Jan, 1997). Tectono-stratigraphically the Himalayas are subdivided in to Sub-Himalayas, Lesser Himalayas, Higher Himalayas and Tethyan Himalayas (Gansser, 1964). The Lesser Himalayan region exhibits folding and faulting. The major tectonic features of the area are Hazara Kashmir Syntaxis, Main Boundary Thrust and Panjal Thrust.

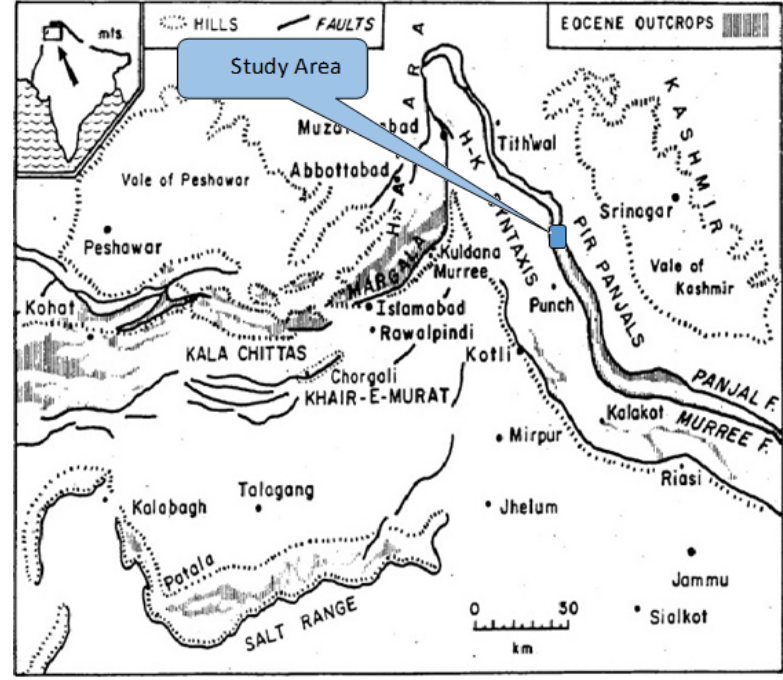

Figure 1: Map of NW Himalaya showing study area (after Wells, N. A. and P.D. Gingerich, 1987).

The study area lies in southwestern part of Pir Panjal range (Fig. 1). Thrust faulting and folding are characteristic in the area. The average strike of the rock sequence is from NW-SE to NNW-SSE. The dip is from $30^{\circ}$ to $75^{\circ}$ in NNE to NE (Fig. 2).

Bossart and Ottiger (1989) misidentified Kuldana Formation as Murree formation. They carried out geological and structural studies of rocks around Muzaffarabad and Balakot area. They considered Kuldana 
Formation as lower part of Murree Formation. The Kuldana Formation was previously recognized and mapped in Muzaffarabad (Khan, 1994) and Kahuta areas (Ashraf and Chaudhry, 1984). The shales of Kuldana Formation show sedimentary cleavage and deformation. The rocks away from MBT are comparatively less deformed and fractured.

\section{Sub-Himalayas}

The Sub-Himalayas are the fold and thrust belt of Neogene molasse sediments extending from Western Pakistan to Assam. The term "Siwaliks" is also used for these deposits. The sub Himalayas in northwestern margin of the Indian plate are comprised of rocks of Rawalpindi and Siwalik groups. The Siwaliks are unconformably overlain by alluvial deposits. Himalayan Frontal Thrust (HFT) marks the southern boundary of the SubHimalayas while the northern boundary is terminated along Main Boundary Thrust (MBT) (Fig. 2)

\section{Lesser Himalayas}

The Lesser Himalayas are comprised of Precambrian to late Paleozoic metasediments intruded by granites, the Cambrian carbonates, Mesozoic and Cenozoic rocks in Hazara and Permian Panjal Volcanics in Kaghan and Kashmir (Greeco, 1989; Bossart et al., 1988). The Lesser Himalayas are very low grade metasedimentary rocks (Heim and Gansser, 1939). The Ordovician to Devonian age rocks are missing. The Lesser Himalayan rocks thrust onto the Sub Himalayas along MBT (Fig. 2).

\section{Higher Himalayas}

The higher Himalayas extends eastward from Indus gorge (near Besham) to Brahamputra gorge in Assam. In North West Himalayas, the Higher Himalayas are comprised of Nanga Parbat range, upper Kaghan and Neelum Valleys.

The high grade metamorphic rocks of Higher Himalayas have thrusted on to the low grade metasediments of Lesser Himalayas along the Main Central Thrust (MCT; Valdiya, 1980). The ductile deformation, barrovian metamorphic sequence, migmatites and leucogranites have been reported in the area (Pecher, 1989). The northern boundary of Higher Himalayas is marked by South Tibet Detachment (STD) normal fault (Fig. 2).

\section{Tethyan Himalayas}

The Tethyan Himalayan zone is comprised of Proterozoic to Eocene siliciclastics as well as carbonate sedimentary rocks (Yin, 2006). Paleozoic to Lower Tertiary marine sedimentary rocks deposited on passive continental margins of the Indian plate are exposed in the Tethyan Himalayas (Liu and Einsele, 1994). Its northern boundary is marked by Indus-Tsangpo Suture Zone (ISMS) where as its southern boundary is marked by South Tibet Detachment Zone (Yin, 2006).

\section{Tectonic Setting of The Project Area}

The Lesser Himalayan region exhibits folding and faulting. The major tectonic features of the area are described as under:

\section{Hazara Kashmir Syntaxis}

Wadia (1931) proposed the term "Northern Himalayan syntaxis" for an abrupt bend similar to shape of a hairpin between Mirpur, Muzaffarabad and Hazara area. The various workers (Calkins et al., 1975; Bossart et al., 1988; Ghazanfar et al., 1986; Ottiger, 1986) have used the name Hazara Kashmir Syntaxis (HKS) for this antiformal structure in the area.

The Main Boundary Fault is folded around the syntaxial bend. The Muzaffarabad fault (MF) and Jhelum Fault (JF) extend from the subHimalayan zone into the core of Hazara Kashmir Syntaxis and are terminated in the area against the MBT (Rustam and Mubarik, 1994; Baig and Lawrence, 1987). Precambrian to recent sedimentary, metamorphic and igneous rocks form its geology.

\section{The Main Boundary Thrust (MBT)}

The Main Boundary Thrust is located near Nauseri, Lamnian and chackama in Muzaffarabad and Khumgala in Kahuta area. In the study area the MBT separates the Panjal Volcanics from the Murree Formation (Fig 2). Wadia $(1928,1931)$ recognized the tectonic discontinuity between the steeply plugging Murree beds and Panjal volcanics in Kahuta and Muzaffarabad areas. The tectonic contact, MBT, is clearly exposed in the study area. The rocks along the contact are highly sheared at places.

\section{The Panjal Thrust}

The Panjal Thrust runs parallel to MBT on the eastern limb of the syntaxis (Wadia, 1931). In Kahuta area it runs through Kalamula-Kiran area. Along the Panjal Thrust the Dogra Slates were thrust on to the Panjal Formation. The Panjal Thrust extends towards southeast in the area.

\section{Stratigraphy of Kahuta Area}

Rocks in the area are from Pre Cambrian to Quaternary and consist of sedimentary, volcanics and metamorphic. The unconformities are marked while some contacts are faulted. The oldest unconformity is between Dogra Slates and Gondwana Group of Carboniferous marked by the presence of conglomerate bed (Fig. 2). Second unconformity is present between Panjal Formation of Permo Carboniferous and Lockhart Limestone of Paleocene age. Chorgali Formation which is marked in other areas is missing here and Patala

Table 1: Stratigraphic column of Kahuta (Modified after Khan, 1994; Ashraf and Chaudhry, 1980)

\begin{tabular}{|c|c|c|}
\hline Formation & Age & Characteristics \\
\hline Quaternary & $\begin{array}{l}\text { Recent to sub } \\
\text { recent }\end{array}$ & $\begin{array}{l}\text { Mainly gravels, boulders, sands but also } \\
\text { some clays, glacial and glaciofluvial } \\
\text { deposits on higher elevations. }\end{array}$ \\
\hline \multicolumn{3}{|r|}{ UNCONFORMITY } \\
\hline $\begin{array}{l}\text { Murree } \\
\text { Formation }\end{array}$ & $\begin{array}{l}\text { Oligocene to } \\
\text { Lower }\end{array}$ & $\begin{array}{l}\text { Reddish brown to greyish, fine to coarse } \\
\text { grained sandstone and reddish shales. }\end{array}$ \\
\hline \multicolumn{3}{|c|}{ UNCONFORMITY } \\
\hline Kuldana & Eocene & $\begin{array}{l}\text { Red, maroon, purple and green shales with } \\
\text { hard sandstone beds. }\end{array}$ \\
\hline $\begin{array}{l}\text { Margala Hill } \\
\text { Limestone }\end{array}$ & Lower Eocene & $\begin{array}{l}\text { Bitumenous black (yellowish grey and flaggy) } \\
\text { limestone. Grey, green and khaki shales. }\end{array}$ \\
\hline $\begin{array}{l}\text { Patala } \\
\text { Formation }\end{array}$ & Late Paleocene & $\begin{array}{l}\text { Creamish to dark brown splintery shale and } \\
\text { subordinate fine to medium grained nodular } \\
\text { limestone. }\end{array}$ \\
\hline $\begin{array}{l}\text { Lockhart } \\
\text { Limestone }\end{array}$ & Paleocene & $\begin{array}{l}\text { Grey to light grey medium to thick bedded, } \\
\text { fossiliferous and nodular limestone. }\end{array}$ \\
\hline \multicolumn{3}{|r|}{ UNCONFORMITY } \\
\hline $\begin{array}{l}\text { Panjal } \\
\text { Formation }\end{array}$ & $\begin{array}{l}\text { Permo- } \\
\text { Carboniferous }\end{array}$ & $\begin{array}{l}\text { Basal agglomeratic slates and basaltic lava } \\
\text { flows. }\end{array}$ \\
\hline $\begin{array}{l}\text { Gondwana } \\
\text { Group }\end{array}$ & Carboniferous & $\begin{array}{l}\text { Basal quartz conglomerate bed, slates and } \\
\text { argillaceous sandstone. }\end{array}$ \\
\hline \multicolumn{3}{|r|}{ UNCONFORMITY } \\
\hline $\begin{array}{l}\text { Kailar } \\
\text { formation }\end{array}$ & Cambrian & $\begin{array}{l}\text { Marble with calcareous schist and quartzite } \\
\text { and dolomite. }\end{array}$ \\
\hline Dogra Slates & Pre-Cambrian & $\begin{array}{l}\text { Grey, dark grey to black slates, The Dogra } \\
\text { slates also contain volcanics which have been } \\
\text { called the "Dogra Trap"' (Wadia, 1928). This } \\
\text { trap is amygdaloidal as well as free from } \\
\text { amygdules. }\end{array}$ \\
\hline
\end{tabular}

Formation exhibits a faulted contact with Kuldana Formation (Fig. 2). Another unconformity is marked between Kuldana Formation of Eocene age and Murree Formation of Miocene age in the area. The stratigraphy of the area is described as under:

\section{Dogra Slates}

Waggen and Wynne (1872) name the group of metamorphic slate rocks in Hazara area, as Attock Slates. Later on Calkins et al., (1969) named it as Hazara Formation. The Dogra Slates are correlated with Hazara Formation on the basis of age, lithology and stratigraphic position (Wadia, 1928).

Dogra Slates are the oldest rock sequence exposed in Kahuta areas (Fig. 2). The petrography and chemical analysis of Dogra Slates is carried out by (Chaudhry and Ashraf, 1984).The rocks form the steep slopes and escarpments. The Dogra Slates show a remarkable color variation from grey, dark grey to black. The slates are fine grained, thin bedded, argillaceous and the cleavage planes being filled with quartz. The volcanics known as Dogra Trap intruded the Dogra Slates. These volcanic rocks have experienced high grade of metamorphism. The Dogra Slates along with Kailar limestone are thrusted over the Paleocene-Eocene Sequence in the area. The rocks of Dogra Trap are basaltic with a high concentration of K2O (Ashraf and Chaudhry, 1980). Lower contact of Dogra Slates is faulted with Kailar formation and the fault is PT. The age of the Dogra Slates is Precambrian (Wadia, 1928).

\section{Kailar formation}

Chaudry and Ashraf (1980) marks Kailar formation as a stratigraphic equivalent of Abbotabad Formation of Latif (1974). It is exposed from Dhund, Maili to Badori ridge and near Kailar Bridge in Kahuta. Kailar formation Consist of marble with calcareous schist, dolomite and quartzite ranging from 15 to 50 meters in thickness in the area. Marble 
is brilliantly white to cremish but at some places pinkish patches are found. Foliation is shown at some places which are marked with chlorite and mica. In the study area the lower contact of Kailar formation is faulted with Kuldana Formation while upper contact is also faulted with Dogra Slates. On the basis of its correlation with Abbottabad Formation tentative age of Cambrian is assigned to these rocks (Chaudhry and Ashraf, 1980).

\section{Panjal Formation}

Middlemiss (1910) called 'volcanic belts' to the volcanic rocks which are present in the apex of Hazara Kashmir Syntaxis. Wadia (1957) named the 'volcanic belt' as Panjal volcanic series. But the name Panjal volcanics is given to these rocks by Calkins et al. (1969).

The volcanic succession is formed by basaltic flows, metaconglomerates, pyroclasts, limestone, slates and schists (Khan, 1994). Dykes and laccoliths of mafic composition are also reported by Wadia (1931). The Panjal volcanics are well exposed in Kahuta, Jhelum, Neelum, and Kaghan areas (Ashraf and Khan, 1993, Khan, 1994). The large volume of the Panjal Volcanics are exposed in the region around Srinagar (Wadia, 1934).

The type locality of formation lies in the "Pir Panjal Range". The Panjal Volcanics are well exposed in the study area (Fig. 2). The agglomerates are comprised of dark grey slates, pyroclastic material embedded in fine grained matrix with meta-conglomerates. At places thin volcanic ash beds are encountered within the agglomerates zone (Khan, 1994). The rocks have been altered and metamorphosed to green schist facie metamorphism. The flows are mainly tholeiitic basalts. In basalt, pyroxene and plagioclase phenocrysts are embedded in fine grained matrix. The lava flows are greenish to dark gray in color. The vesicles are filled with secondary material (Amygdaloidal), (Ashraf and Khan, 1993). In the study area the lower contact of Panjal formation is faulted with Murree Formation while upper contact is unconformable with Lockhart Limestone. Wadia (1928) assigned Carboniferous to Permian age to Panjal volcanics.

\section{Gondwana Group}

Chaudhry and Ashraf (1980) called it "Gondwana group" and marked at some places between Kalamula and Hillan in Betar valley (Fig. 2). Medlicott (1876) proposed this name in an un-published portion of his report. On the south side of Pir Panjal, Wadia (1928) marked a great thickness of moderately metamorphosed shale, quartzites and argillaceous sandstone as Gondwana rocks.

The Gondwana rocks are unconformably underlain by Dogra Slates. The unconformity is marked by very coarse boulder conglomerate. This group consists of conglomerate bed comprised of well-rounded quarts, cobble, and pebble. The percentage of particles is 50 to $70 \%$ and the thickness of this bed is 25 to 50 meters (Ashraf and Khan, 1993). The arenaceous, phyllitic and sandy slates of black, green to grey color are found. Total thickness of Gondwana Group is 125 meters and is marked as of Carboniferous age.

\section{Lockhart Limestone}

Davies (1930a) marked Paleocene Limestone in Kohat area and named as Lockhart Limestone which is approved by stratigraphic committee of Pakistan. Previous authors marked this unit with different names like 'Nummulitic Series' by Middlemiss (1896), 'Khairabad Limestone' by Gee (1934), 'Tarkhobi Limestone' by Eames (1952) and 'Marl Limestone' by Latif (1970). Wynne (1873) and Cotter (1933) marked it as lower part of 'Hill Limestone'.

The limestone is grey, medium to massive bedded and brecciated. Its lower part is flaggy and dark blue to grey in color. Its thickness is 36 meters in type section. Limestone of this formation in Salt Range and Trans-Indus Ranges is grey, medium bedded and nodular. In lower part marl of grey color with dark blue calcareous shales are present. Type section of this formation is near Fort Lockhart in Samana Range. In Kala Chitta and Hazara areas the Lockhart Limestone is dark grey to black and embedded marl and shales. In Azad Kashmir Lockhart Limestone is well exposed in Muzaffarabad and Kotli. Munir et al., (2006) worked on the formation in Yadgar area near Muzaffarabad and Tattapani near Kotli. Dominant fossils of this formation are foraminiferas with algae, corals, molluscs, echinoids, miscellanea miscella (Latif, 1970), operculina, lockhartia sp, Discocyclina ranikotensis, Assilina sp and Nummulites sp (Davies and Pinfold, 1937).

In Kahuta area, it is mainly a calcareous, nodular limestone with subordinate shales in the lower and upper parts. The limestone is grey, medium to thick bedded, medium grained and hard. The weathered surfaces indicate solution weathering and blue to light grey in color. On fresh surface it is generally dark grey and gives a foetid smell by hammering. There is a marked decrease of nodules towards the middle part of the unit. Nodularity increases towards its contact with the overlying shale of the Patala Formation. The nodular habit of the limestone appears to be of sedimentation origin. This origin is supported by the fact that the nodules are more frequent where shale is interbedded with limestone. Nodules are generally $2-6$ centimeters in length and 1-5 centimeter in width. In the middle part of the unit calcite veins are common. Topographically the formation forms ridges and cliffs. It is highly fossiliferous and fossil size from $0.5-1.5 \mathrm{~mm}$. However previously fossils were never recorded in the area. In study area, the lower contact of Lockhart Limestone is unconformable with Panjal Formation while upper contact is normal at some places with Patala Formation and at some places it is faulted with Kuldana Formation. On the basis of fossils it is marked as Paleocene age.

\section{Patala Formation}

The name Patala Formation is accepted by the stratigraphy of Pakistan to replace its earlier names "Patala shales" of Davis and Pinfold (1937), "Tarkhobi shales" of Eames (1952).

The lithology of formation is shale and marl, with subordinate flaggy limestone and sandstone in the Salt Range area (Shah, 2009). These shales are greenish grey and calcareous while limestone is nodular with light grey color. Sandstone is interbedded in the upper part. Type section of the formation lies in the Patala Nala, Western Salt Range. In Dandot area coal seems were reported. In Kohat area shales and limestone shows dark grey color. In Hazara and Kala Chitta area grey argillaceous limestone beds were interbedded with shales and marl and its thickness is 20-182 meters while in surghar range its thickness is from 30-75 meters (Shah, 2009).

In the study area the dark greenish grey carbonaceous shale and limestone is found. Limestone is interbedded with shale near the base. Due to faulted contact very small patch is marked near Khumgala which formed slope escarpment. In the study area the lower contact of Patala Formation is conformable with Lockhart Limestone while upper contact is faulted with Kuldana Formation. It is assigned as Paleocene age.

\section{Margalla Hill Limestone}

The stratigraphic committee of Pakistan formally assigned the name "Margalla Hill Limestone" after the work done by Latif (1970). "Nummulitic formation" name was given by Waagen and Wynne (1872). "Hill Limestone" name was proposed by Wynne (1873) and Cotter (1933). "Nummulitic Series" was assigned by Middlemiss (1896). The name is basically derived from Margalla hills in Hazara.

The lithology of formation is represented by thick bedded, nodular, medium grained limestone with interbeds of brownish grey marl and greenish brown shale. The limestone is nodular and medium to thick bedded. Its thickness varies from 80-100 meters. The type section of the formation lies in the Shahdara section of the southeastern Hazara. Sections of Margalla Hill Limestone were also marked in Kala Chitta Range, Kohat and Potwar areas. The formation is well exposed in Muzaffarabad, and Kotli areas. Ashraf and Khan (1993) marked greenish grey nodular beds as Margalla Hill Limestone in the Kahuta area. However during field investigation the formation was not encountered in the study area. It is marked as early Eocene age.

\section{Kuldana Formation}

The stratigraphic committee of Pakistan formalized the name "Kuldana Formation" after the work done by Latif (1970). "Kuldana beds" name was given by Wynne (1874). "Kuldana Series" mane was assigned by Middlemiss (1896). Pinfold (1918) called them "variegated shales". Eames (1952) suggested the name Lower Cherat series. Lithology of the formation consist of mainly shale and marl. Shales are gypsiferrous and arenaceous with variegated colors. Beds of sandstone, limestone, conglomerate and dolomite were found occasionally. Type section of the formation is in Kuldana Village near Murree. This formation is well exposed in Hazara, Kala Chitta, Kohat and Potwar area. The formation is also exposed in Jhelum, Neelum, Kaghan and Kotli areas. In Kahuta it is well exposed in Kailar, Khursheedabad and Hajibal area. It consists mostly of bright red and purple shales. Mostly red shales are intercalated with green shales along the dip slope. Sandstone beds were found near the base of Kuldana Formation. Sandstone of 
Kuldana Formation is fine to medium grained. Its thickness is 210 meters in the study area. The lower contact is faulted with Patala Formation at some places and in some places with Lockhart Limestone. While upper contact is also faulted with overlying Kailar formation. Age assigned to Kuldana Formation is Eocene.

\section{Murree Formation}

The name Murree Formation is replaced after "Mari group" of Wynne (1874). "Murree beds" was suggested by Lydekker (1876). "Murree series" was assigned by Pilgrim (1910) In type section dark red and purple clay and purple grey and greenish grey sandstone with minor intraformational conglomerates found in the formation. The basal strata of formation also designated as Fatehjhang member is composed of calcareous sandstone, conglomerates and foraminifers of Miocene age. Sandstone of upper Murree is different from lower Murree as it is medium to coarse grained and grey and brown in color while sandstone in lower Murree is fine grained and purple. Shales of upper Murree are purple, reddish, and brownish in color and contains plant fossils. Its maximum thickness is 1830 meters (Wadia, 1928).

Type section of formation lies towards the north of Dhok Maiki in the Attock district. The formation is widely exposed in Salt Range, KohatPotwar, Kahuta, Rawalakot, Bagh, Neelum, Jhelum and Kaghan areas. The topographic features of formation in Kahuta area includes ridges, valleys, escarpments and dip slopes. It is composed of alternate beds of sandstone and shale. In Kahuta area it has faulted contact with Panjal Formation and the fault is MBT. The age of the formation is early Miocene.

\section{Quaternary Alluvium}

The Quaternary alluvial deposits rests uncomfortably on Neogene molasse sediments. The Quaternary is comprised of conglomerates, sand and clays. The conglomerates are of variable size and shape. The provenance is sedimentary, igneous and metamorphic rocks.

\section{Maerials and Methods}

The formation selected for research work is Kuldana Formation of Eocene age, exposed in Kalamula and Khursheedabad areas (Figs. 2). The Kuldana Formation comprised of shale and sandstone exposed in the area. It is dominantly composed of shales of variegated color in Kalamula (Fig. 11). The alternating red and green color shales are dominating in the formation. The sandstone beds of greyish green to maroon color, medium bedded, fine to medium grained and well compacted occur in the formation. The Lower contact of Kuldana Formation is faulted with Patala Formation while the upper contact is also faulted with Kailar formation of Ashraf \& Chaudhry (1980).

The field work was carried out in the study area to obtain geological data and collection of rock samples by using Topographic sheet and instruments like Brunton compass, hammer Hand lens (10x) and camera. This research study was completed in two phases, field and laboratory work. Field work consists of

$\begin{array}{ll}\text { 1. } & \text { Collection of rock samples for petrographic studies } \\ 2 . & \text { Outcrop sections photography } \\ 3 . & \text { Recording of geological data }\end{array}$

4. Stratigraphic section measurement of the area

Toposheet no. 43K/1 of the Survey of Pakistan was used to prepare sample location and geological map (Fig. 2) of the area. LEICA DM750 polarizing microscope with attached LEICA EC3 camera was used for thin sections study in the petrology laboratory of the Institute of Geology.

Thirteen sandstone samples of Kuldana Formation were selected for petrographic studies and preparation of thin sections. Section measurement was started from the basal contact of Kuldana Formation to its upper contact with Kailar formation. The thickness of Kuldana Formation is $203 \mathrm{~m}$ in the section. The laboratory work included cuttings of the rock samples for the preparation of thin sections. The thin sections were prepared to get maximum textural mineralogical and diagenetic study. The microscopic study of thin sections was carried out under Polarizing microscope (LEICA DM750P) for identification of constituent minerals, determination of model mineralogical composition, extent of variation in particles size, degree of roundness of the framework grains and classification of sandstone. Photographs of important features were also taken.
Ten samples of Kuldana shales were also taken for $\mathrm{x}$-ray diffraction analysis (XRD). XRD analyses were performed in laboratory to obtain peak graph and identification of shale mineralogy (Figs. 8, 9). The recalculated value of the calcite, quartz and clay were plotted on the diagram which marked shales as argillaceous (Fig. 5). While giving a number to the sample, the grid reference of the sample was recorded in the field note book and also on the sample, using this data the sample location map of the area was prepared.

\section{Results and Discussion}

\section{Petrography of Kuldana Formation}

Petrography is the discipline of geology that involves microscopic study of thin sections under microscope in order to determine mineralogy, composition and textures as well as to classify sandstone and deduce sediment transport history, provenance and tectonic setting, maturity indices and paleoclimates. Thin sections of sample were prepared, labelled and studied under petrographic microscope. The photomicrographs were taken. In sandstone the relative abundance of each mineral grain is also shown in Table. 2. The detail microscopic study of rocks of Kuldana formation and carbonate were carried out. The study includes the petrography of sandstone of Kuldana Formation.

For the petrological study of Kuldana Formation the samples were taken in areas of varied lithology such as change in color, grain size or contacts. The samples were plotted on the sample location map (Fig. 2). Thin sections were prepared for the petrographic studies. The modal mineralogical data of sandstone of Kuldana Formation of Kalamula section is shown in Table 2.

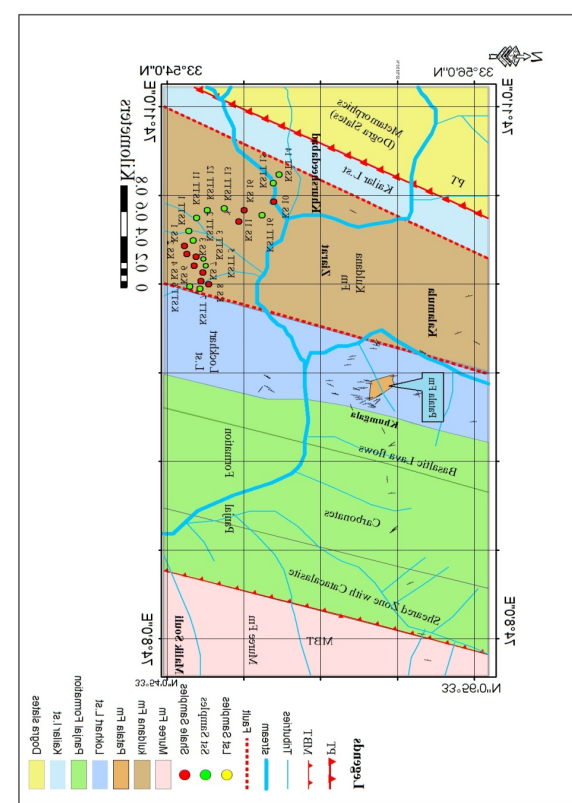

Figure 2: Geological and sample location map of the project area.

\section{Results and Discussion}

The petrological study of sandstone of Kuldana Formation of Kalamula section shows the amount of quartz grains varies from 37-62\%. Monocrystalline quartz grains are most common than the polycrystalline quarts. In Kalamula section the contact between quartz grains are planner, point, sutured and concavo-convex. Zircon (Fig. 3c) and apatite inclusions (Fig. 3b) are common in quartz grains. Most of the quart grains are sub angular (Fig. 3a) to sub rounded (Fig. 3d). Rounded (Fig. 3d) and elongated quartz grains (Fig. 3a) are also identified. The amount of feldspar grains in thin section ranges from 5-12\%. Plagioclase (Fig. 3e), orthoclase (Fig. 3f) and perthite (Fig. 3g) are commonly identified in maximum thin sections while microcline (Fig. $3 \mathrm{~h}$ ) is rarely found in Kalamula section. Plagioclase is abundant as compared to alkali feldspar. In some thin sections the alteration of feldspar into sericite (Fig. 4a), calcite (Fig. 4b) and clay is observed.

The average percentage of rock fragments range from $9-28 \%$ in abundance. The rock fragments of volcanic rocks (Fig. 4c), metamorphic grains including slate, phyllite, schist (Fig. 4d) and quartzite (Fig. 4d) are present. Sedimentary clasts includes siltstone (Fig. 4a), sandstone, 
adolomite (Fig. 4a) and limestone (Fig. 4f) in the rocks.

Calcite (Fig. 4b), hematite (Fig. 4b), chlorite (Fig. 5b) and clays (Fig. $4 \mathrm{~b}$ ) ct as a cementing material. Cement constitutes $13-32 \%$ of bulk volume of the rock. Calcite is the most abundant cement in the sandstone. Hematite also appear as cement in some rock samples while clay and chlorite is also found in considerable amount (Table 4.2).

In Kalamula section the percentage of accessory minerals range from 6-12\% Hematite, pyrite (Fig. 4h), tourmaline (Fig. 5a), chlorite (Fig. 5b) muscovite (Fig. 5e), zircon (Fig. 3c), epidote (Fig. 3b), apatite (Fig. $3 \mathrm{~b}$ ), and sphene (Figs. 5c, 5d) are common accessory minerals in this section.

In order to classify the sandstones of Kuldana Formation, the recalculated values of quartz, feldspar and rock fragments were plotted on equilateral triangle of Blatt and Tracy (1996). According to Blatt and Tracy (1996) arenite have less than 5\% clay matrix in its composition and wacke sandstone have more than $5 \%$ clay matrix. The sandstones were classified as lithic graywackes (Table. 3). Twelve fragment of lithic graywackes taken from sandstone bed was selected for petrography and all samples have more than $5 \%$ matrix.

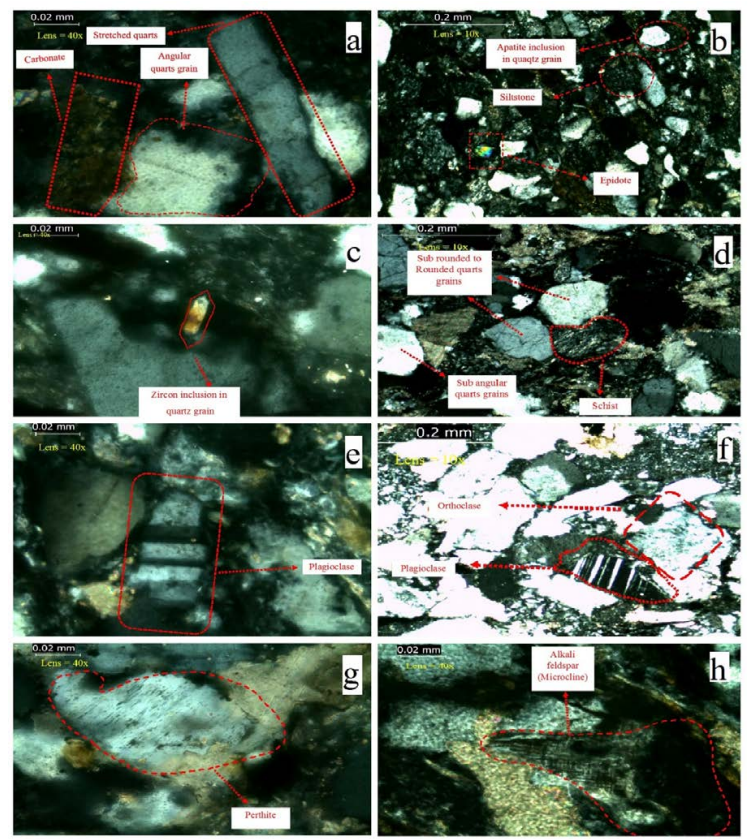

Fig.3 a: Photomicrograph showing stretched quartz grain, angular quartz grain as well as angular carbonate grain. Fig.3 b: Photomicrograph showing epidote grain, siltstone grain and apatite inclusion in quartz grain. Fig.3 c: Photomicrograph showing zircon inclusion in quartz. Fig.3 d: Photomicrograph showing rounded quartz grains and schist. Fig.3 e: Photomicrograph showing plagioclase grain Fig.3 f: Photomicrograph showing orthoclase and plagioclase grains with chlorite as a cementing material. Fig.3 g: Photomicrograph showing perthite grain. Fig. 3 h: Photomicrograph showing alkali feldspar (Microcline) grain.

\section{Tectonic Provenance of Sandstone}

The source of sandstone constituents is determined by plotting the recalculated values of quartz, feldspar and rock fragments on provenance discrimination diagram of Dickinson et al. (1983). The modal mineralogical data of sandstones fall in the field of recycled orogeny (Fig. 7). In Pakistan previously provenance of Sabathu Formation was describes as recycled orogeny by Najman and Garzanti, (2000). Blatt and Tracy, (1996) suggested that sandstone containing more than 5\% matrix in composition and are classified as graywackes. The Kuldana sandstone is classified as Lithic graywacke using the criterion of matrix content (Fig. 6).

The clastic sediments and minerals are useful for determining provenance of sandstone (Dickinson, 1983). The climate and relief of the source region are also important in the supply of detritus (Blatt and Tracey, 1996). The sandstone provenance studies also reveal the ancient tectonic history of the area. The provenance of sandstone of Eocene Kuldana Formation in Kahuta area is determined by using quartz, feldspar, heavy minerals and rock fragments.

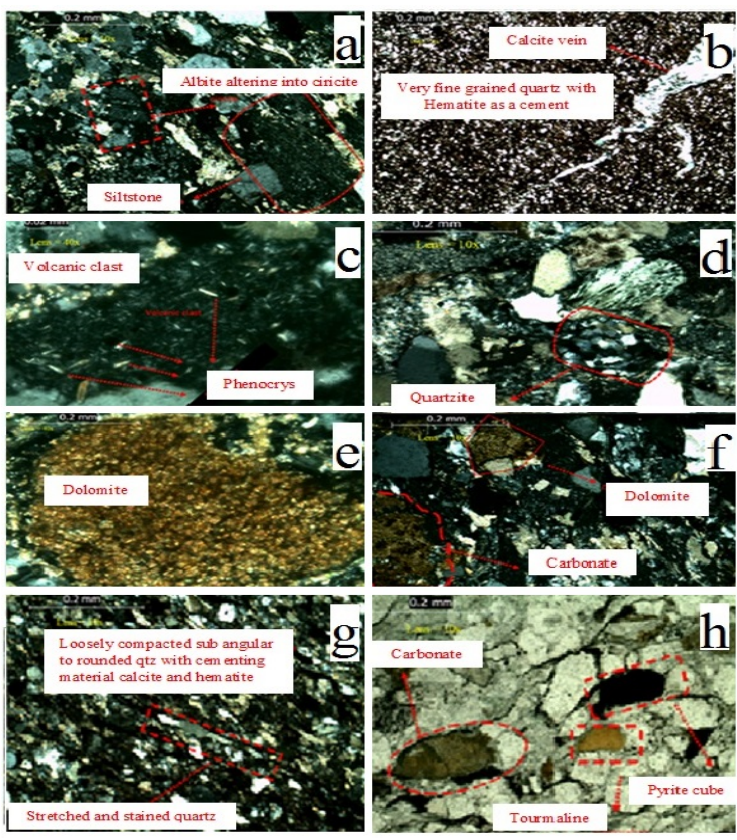

Fig.4 a: Photomicrograph showing siltstone fragment in right and alteration of albite grain into sericite on the left. Fig.4 b: Photomicrograph showing calcite vein and very fine grained quartz with hematite and clays as a cementing material. Fig.4 c: Photomicrograph showing plagioclase phenocryst in a volcanic clast. Fig.4 d: Photomicrograph showing fragment of schist and quartzite. Fig.4 e: Photomicrograph showing dolomite clast. Fig.4 f: Photomicrograph showing limestone and dolomite grains. Fig.4 g: Photomicrograph showing loosely compacted sub angular to rounded quartz with cementing material calcite and hematite as well as stretched and stained quartz. Fig.4 h: Photomicrograph showing clasts of carbonate, tourmaline and pyrite cube.

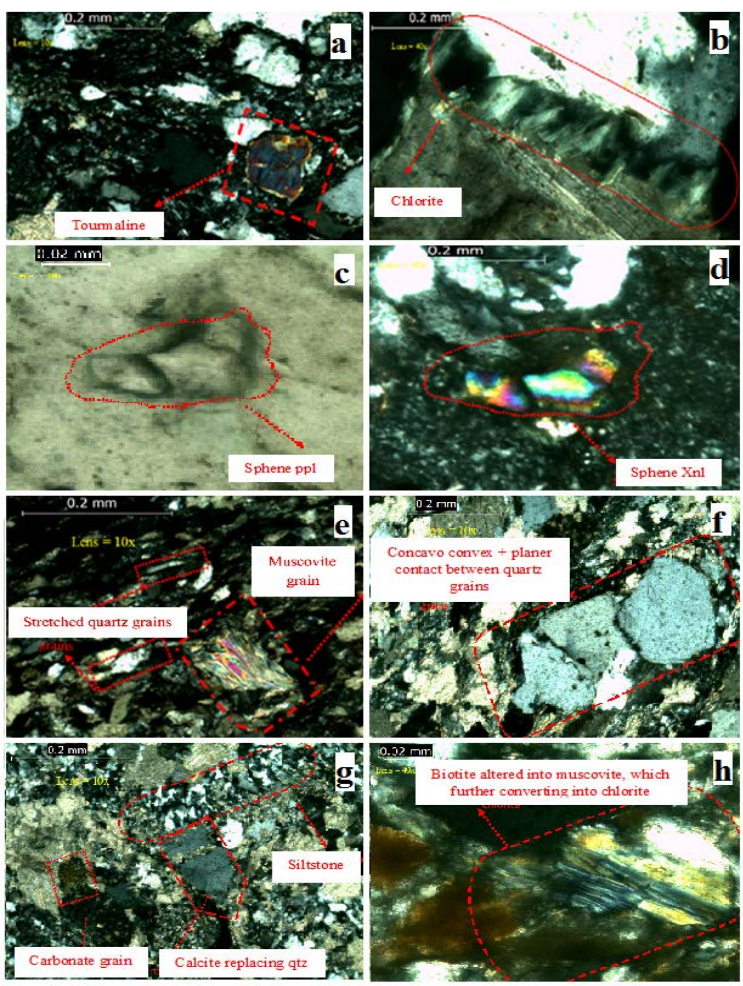

Fig.5 a: Photomicrograph showing tourmaline grain. Fig.5 b: Photomicrograph showing chlorite grain. Fig.5 c: Photomicrograph showing sphene grain (ppl). Fig.5 d: Photomicrograph showing sphene grain (x-nikle). Fig.5 e: Photomicrograph showing muscovite grain and stretched quartz grains. Fig.5 f: Photomicrograph showing planer, as well as concavo convex contact in quartz grains. Fig.5 g: Photomicrograph showing siltstone and carbonate grain while quartz grain is replaced by calcite. Fig.5 h: Photomicrograph showing alteration of biotite into muscovite which further altering into chlorite. 


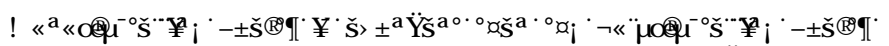

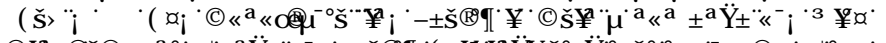

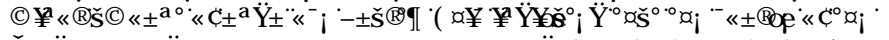

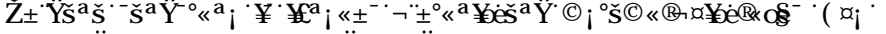
ए

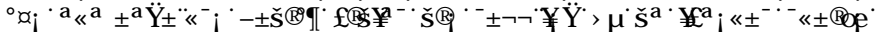
ए ए ए प प

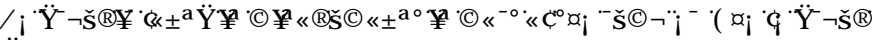

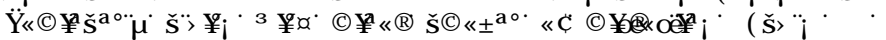

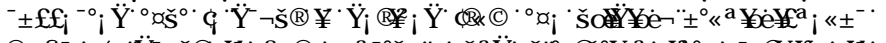

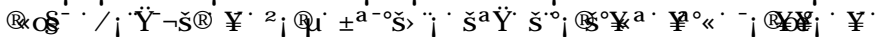
ए

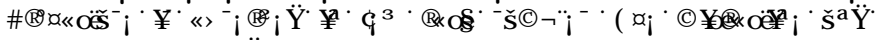

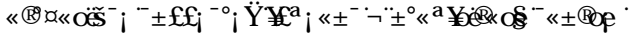

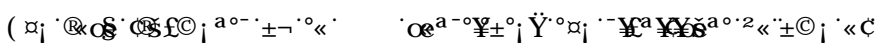

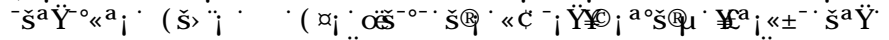

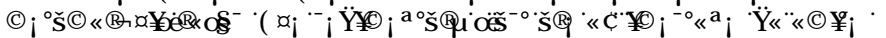

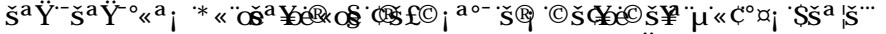

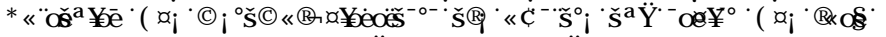
ए पएW प

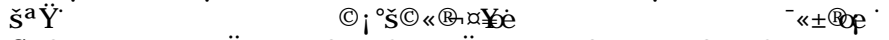

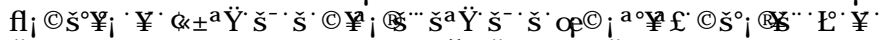

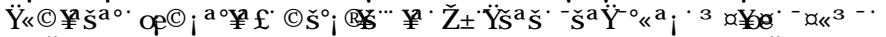

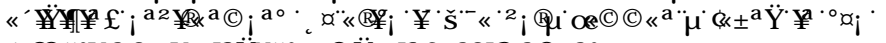

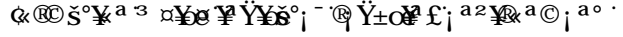

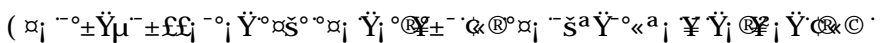

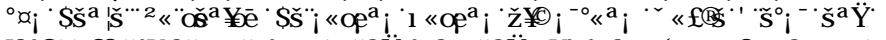

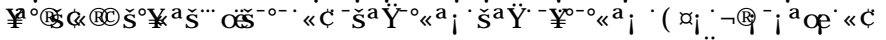

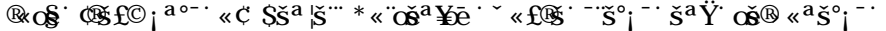

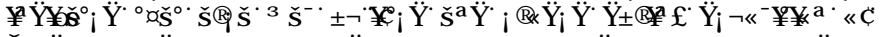

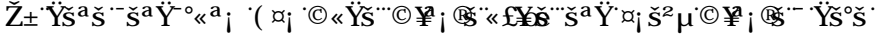

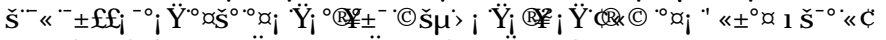

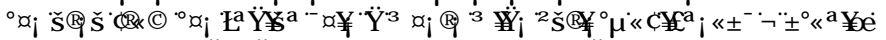

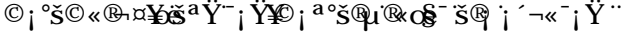

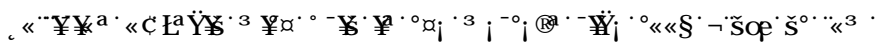

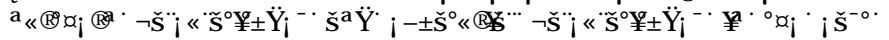

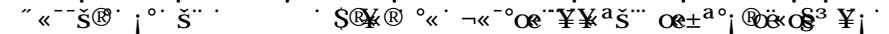

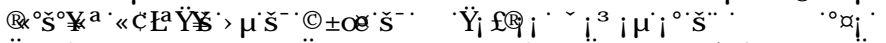

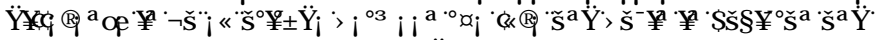

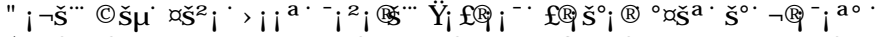

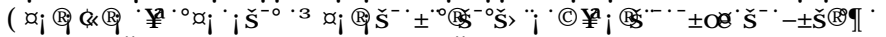

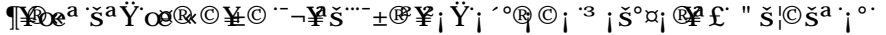

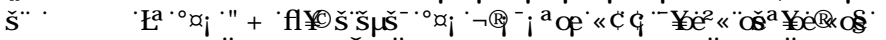

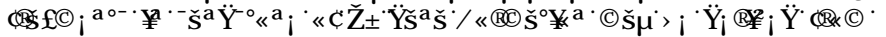

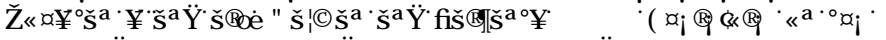

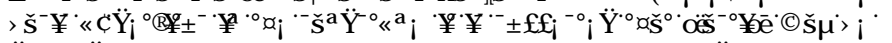

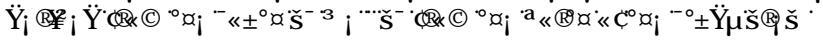

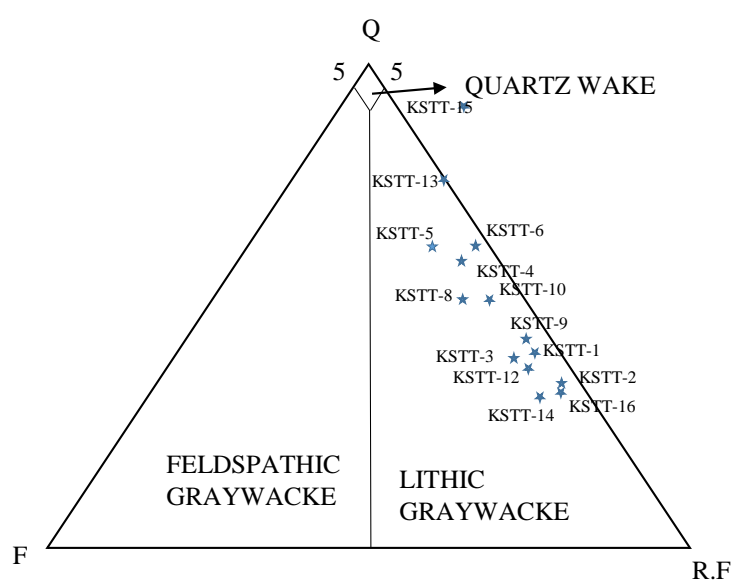

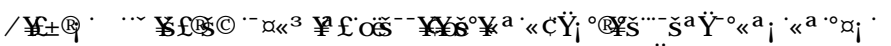

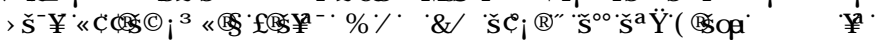

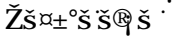

CRATON INTERIOR Q

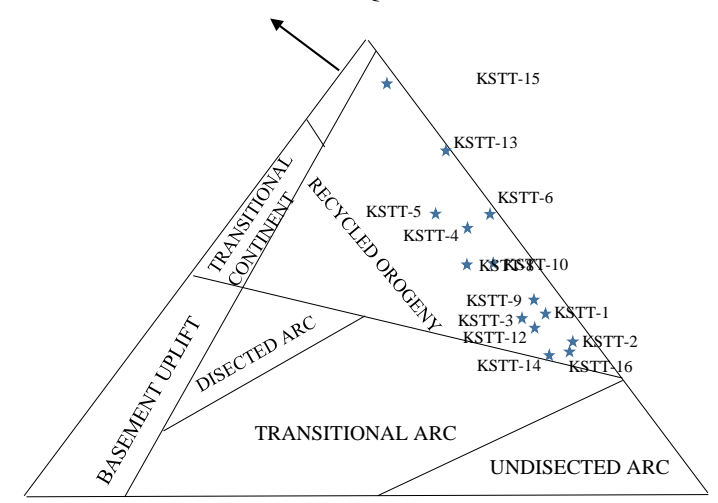

5】)

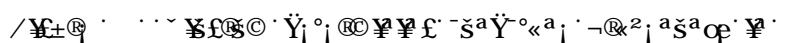
ए

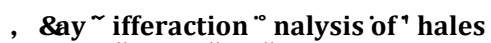

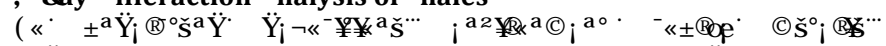

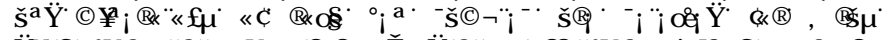

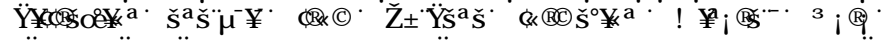

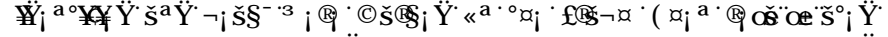

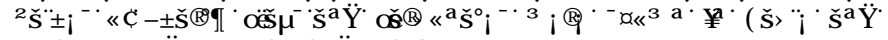

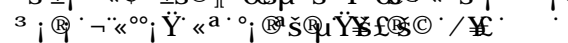

\section{()}

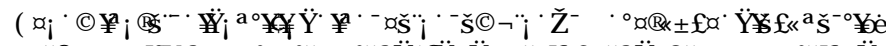

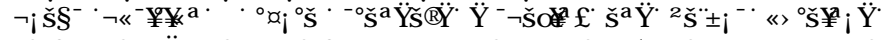
ए ए

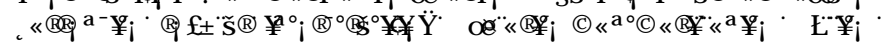

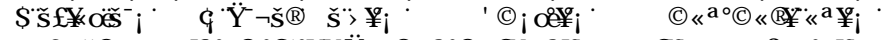

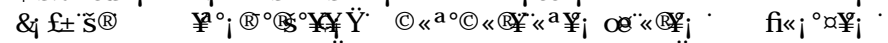

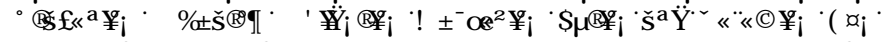

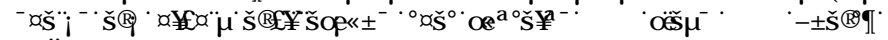
एवा

\section{ब(ॅ)}

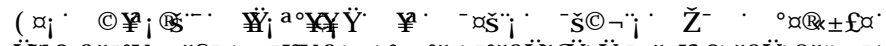

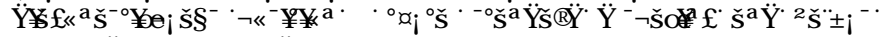

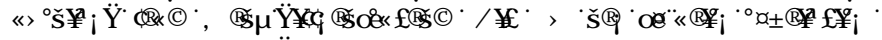
एव

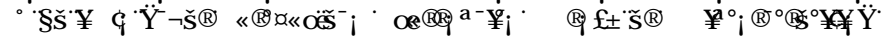

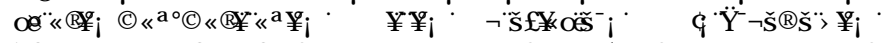

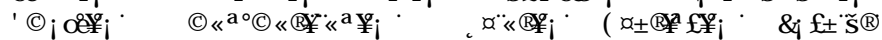
ए

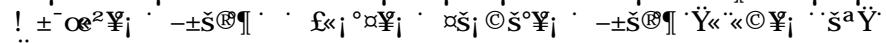

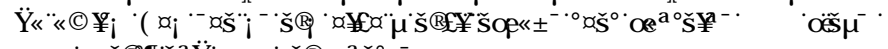

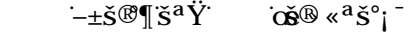

\section{ब(ॅ)}

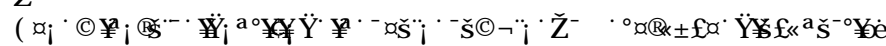

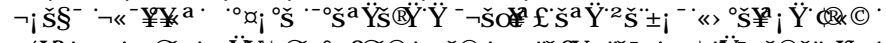

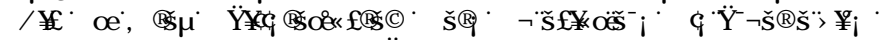

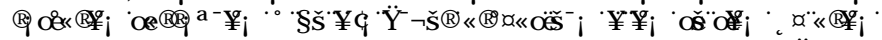
प

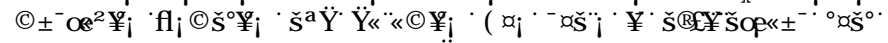

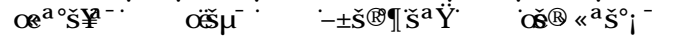

\section{ФĞ}

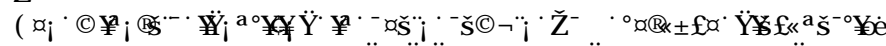

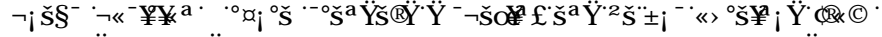

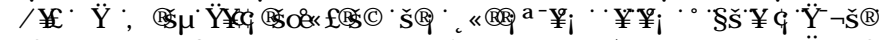

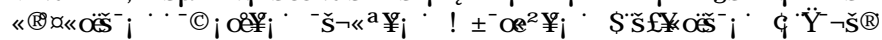

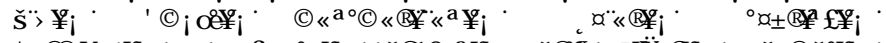

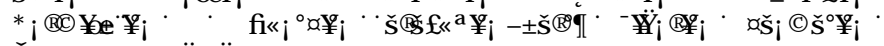

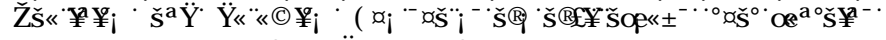

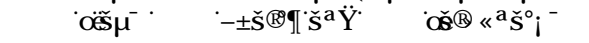

\section{ब)ढ̆}

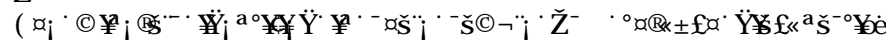

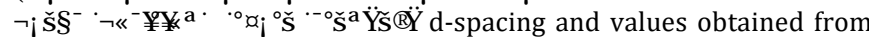
(Fig. 9a) X-ray differactogram are Corrensite, Regular interstratified montmorillonite -chlorite, quartz, chlorite thuringite, Chloritepenninite, Goethite, Pyrite, Siderite, Muscovite, Hematite and Dolomite. The shales are Silicious that contains 55\% quartz, 38\% clays and 7\% carbonates. 
Ks-6

The minerals identified in shale sample Ks-6 through diagonastic peaks, position 2 theta, standard d-spacing and values obtained from (Fig. 9b)X-ray differactogram are corrensite, rectorite regular interstratified mica-montmorillonite, quartz, plagioclase feldsparalbite, illite, smectite montmorillonite, Chlorite thuringite, goethite, Pyrite, calcite, Muscovite, Hematite, and dolomite. The shales are argillaceous that contains $76 \%$ clay minerals, $19 \%$ quartz and $5 \%$ carbonates.

\section{Ks-7}

The minerals identified in shale sample Ks-7 through diagonatic peaks, position 2theta, standard d-spacing and values obtained from (Fig 9c) X-rav differactooram are correncite chlorite thurinoite illite
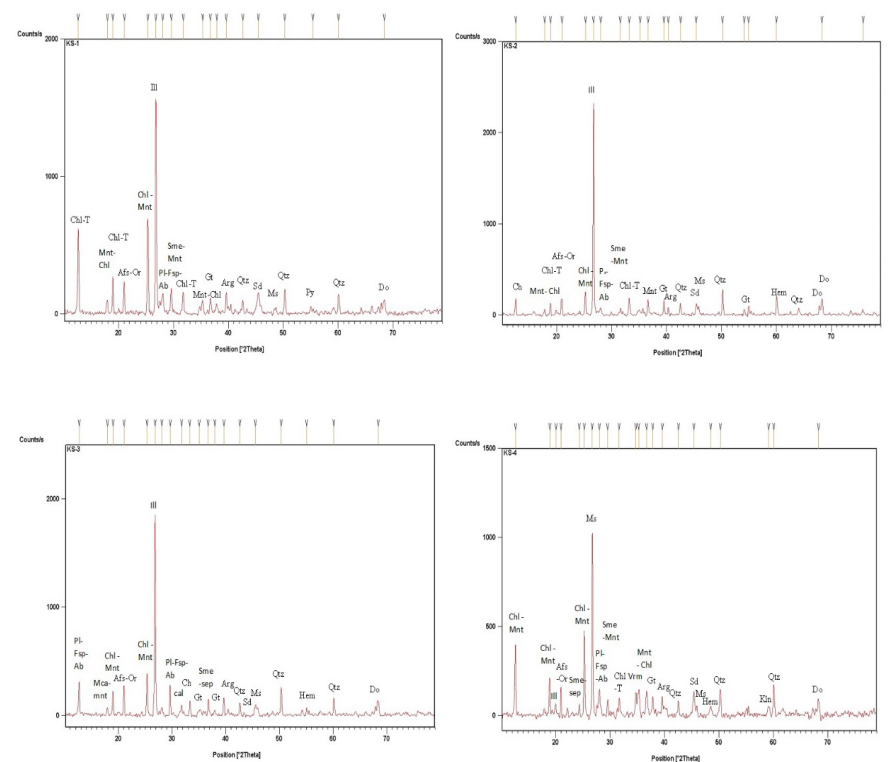

Fig.8 a: X-ray diffraction graph of Kuldana Formation shale (KS-1) in kahuta section display major peaks of: Ill (Illite), Chl-T (Chlorite Thuringite) and Chl- Mnt (chlorite montmorillonite). Fig.8 b: X-ray diffraction graph of Kuldana Formation shale (KS-2) in kahuta section display major peaks of: Ill (Illite), Chl- Mnt (chlorite montmorillonite) and Chl-T (Chlorite Thuringite). Fig. 8c: X-ray diffraction graph of Kuldana Formation shale (KS-3) in kahuta section display major peaks of: Ill (Illite), Chl- Mnt (chlorite montmorillonite) and Pl-Fsp-Ab (Plagioclase Feldspar Albite). Fig.8 d: X-ray diffraction graph of Kuldana Formation shale (KS-4) in kahuta section display major peaks of: Ms (Muscovite), Chl- Mnt (chlorite montmorillonite) and Qtz (Quartz).

quartz, plagioclase feldspar-albite, calcite, aragonite, Regular interstratified montmorillonite -chlorite, pyrite, siderite, muscovite, haematite and dolomite. The shale are siliceous that contains $68 \%$ quartz, $14 \%$ clays and $18 \%$ carbonates.

$K s-8$

The minerals identified on shale sample Ks-8 through diagonastic peaks, position 2 theta, standard d-spacing and values obtained from (Fig. 9d) X-ray differactogram are Chlorite Thuringite, Alkali feldspar orthoclase, plagioclase feldspar-albite, Smectite saponite, Corrensite regular interstratified Chlorite-montmorillonite, illite, calcite, Aragonite, Goethite, quartz, Pyrite, siderite, aragonite, Rectorite Regular interstratified mica- montmorillonite, Hematite, quartz and dolomite. The shale are argillaceous that contains, $62 \%$ clays, $25 \%$ carbonates and $13 \%$ quartz

$K s-9$

The minerals identified in shale sample Ks-9 through diagonastic peaks, position 2 theta, standard d-spacing and values obtained from (Fig. 9e) X-ray differactogram are Chlorite Thuringite, Corrensite regular interstratified chlorite-montmorillonite, Quartz, Muscovite, Plagioclase feldspar albite, Vermiculite, Regular interstratified Montmorillonite-chlorite, Goethite, Pyrite, Siderite, Dolomite and Hematite. The shales are argillaceous, that contains 52\% clays, 32\% quartz and $16 \%$ carbonates.

\section{$K s-10$}

The minerals identified in shale sample Ks-10 through diagonastic peaks, position 2 theta, standard d-spacing and values obtained from
(Fig. 9f) X-ray differactogram are Chlorite Thuringite, Muscovite, Corrensite regular interstratified chlorite-montmorillonite, Quartz, Illite, Plagioclase feldspar albite, Smectite saponite, Goethite, Pyrite, Siderite, Hematite and Dolomite. The shales are argillaceous, that contains $74 \%$ clays, $18 \%$ quartz and $8 \%$ carbonates.
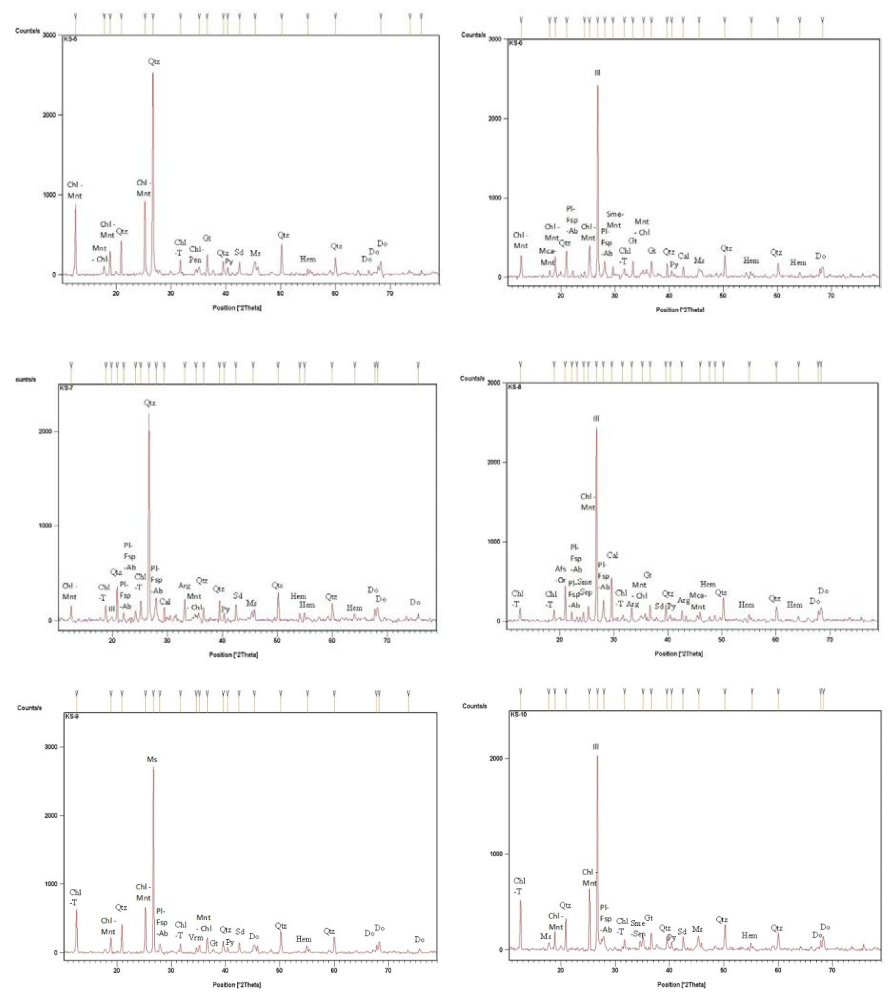

Fig.9 a: X-ray diffraction graph of Kuldana Formation shale (KS-5) in kahuta section display major peaks of: Qtz (quartz, Chl-Mnt (Chlorite montmorillonite) and Chl-T (Chlorite Thuringite). Fig.9 b: X-ray diffraction graph of Kuldana Formation shale (KS-6) in kahuta section display major peaks of: Ill (Illite), Chl- Mnt (chlorite montmorillonite) and Qtz (Quartz). Fig.9 c: X-ray diffraction graph of Kuldana Formation shale (KS-7) in kahuta section display major peaks of: Qtz (Quartz), Pl-Fsp-Ab (Plagioclase feldspar albite) and Arg (Aragonite). Fig.9 d: Xray diffraction graph of Kuldana Formation shale (KS-8) in kahuta section display major peaks of: Ill (Illite), Cal (Calcite) and Afs-Or (Alkali feldspar orthoclase). Fig.9 e: X-ray diffraction graph of Kuldana Formation shale (KS-9) in kahuta section display major peaks of: Ms (Muscovite), Chl-Mnt (chlorite montmorillonite) and Chl-T (Chlorite Thuringite). Fig.9 f: X-ray diffraction graph of Kuldana Formation shale (KS-10) in kahuta section display major peaks of: Ill (Illite), ChlMnt (chlorite montmorillonite) and Chl-T (Chlorite Thuringite).

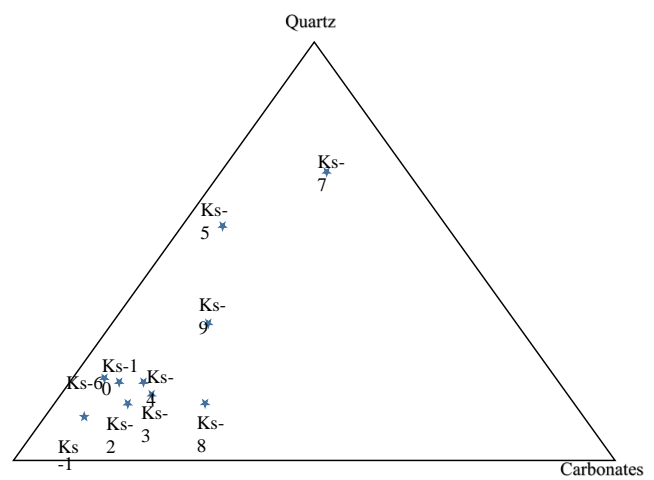

Figure 10:Ternary diagram showing percentge of quartz, clays and carbonates in shales and clays in Kahuta area.

\section{Diagenesis of Kuldana Formation}

The diagenesis is change in loose sand to a sandstone body characterized by specific texture, strength, composition and porosity. Von Gumbel, (1888) use the term diagenesis to include all the postdepositional changes that took place in the sandstone from Kuldana Formation of Middle Eocene age. Diagenesis includes postdepositional physical and chemical processes in which loose sediments are transformed in a hard rock. When uncemented loose sands is deposited, due to lithostatic 
pressure, the physical process of compaction starts which reduces the interparticle porosity. Oxidation or reduction indicates the early chemical diagenetic processes. According to Dapples (1979), the initial stage of diagenesis comprises the main lithification phase and involves compaction, compression (deformation), cementation, crystallization and recrystallization.

Sandstone diagenesis is process controlled by sediment source, depositional system and sediments burial environment (Reed et al., 2004). The physical and chemical process affects the detrital sediments including the chemistry of pore water. The fabric of sandstone of Kuldana Formation exhibits a minor change by physical compaction after deposition which reduce pore volume by affecting the arrangement of sand grains. The lithostatic pressure affected the sand grains of the Kuldana Formation. The grains in the sandstone exhibit the planner, concavo-convex and sutured contacts. The burial depth increases the rate of compaction in sandstone. This cause dissolution between quartz grains of similar solubility and point contacts are changed into sutured contacts in the sandstone (Fig. 1b).

The alteration of minerals is also a major diagenetic change. The monocrystalline quartz grains are replaced by carbonate cement (Fig. $5 \mathrm{~g}$ ). The corroded and etched margins of quartz grains indicated late diagenetic in sandstone. They originated during replacement of quartz by calcite (Fig $5 \mathrm{~g}$ ).

Another diagenetic change is the alteration of feldspar minerals, mica and rock fragments into clay minerals. The alteration is caused by pore and ground water interaction with feldspar which altered feldspar into clay minerals. Chlorite is also a clay mineral which is formed by the alteration of biotite and muscovite. The major alteration of minerals in the sandstone of Kuldana Formation is the alteration of mineral biotite into muscovite which further altered into chlorite (Fig. 5h).

A major diagenetic feature is cementation of a rock. The dominant cement in the sandstone of Kuldana Formation is calcite, hematite and chlorite. Calcite is the common carbonate cementing material in the sandstones of the Kuldana Formation. The carbonate cementing material is derived from dissolution of carbonate rock fragments in the sandstone and ground and surface water containing ions of carbonates. It indicates that the common cement in sandstones is carbonate cement. In alkaline pore solutions, calcite is precipitated (Selley, 1982).

\section{Depositional Environment of Kuldana Formation}

A natural geographic entity where sediments are accumulated characterized by physical, biological and chemical conditions is termed as depositional environment.

The Kuldana Formation is dominantly comprised of calcareous shales and clay with fine to medium grained sandstone beds near base. The shale and clay are purple, red, buff, green, greenish grey, crimson, maroon and pale grey to brownish grey. XRD analysis of shale indicate that maroon color is due to presence of goethite and pyrite which indicates reducing environment. Chlorite gives green color to shales and indicates reducing environment. Clay minerals smectite, montmorillonite, chlorite and illite are recognized through XRD analysis of shales. Carbonate minerals siderite, calcite, dolomite and aragonite are present in shales.

The sandstone are of grey to dark grey and maroonish color in the field. Maroonish color in sandstone is due to presence of hematite cementing material.

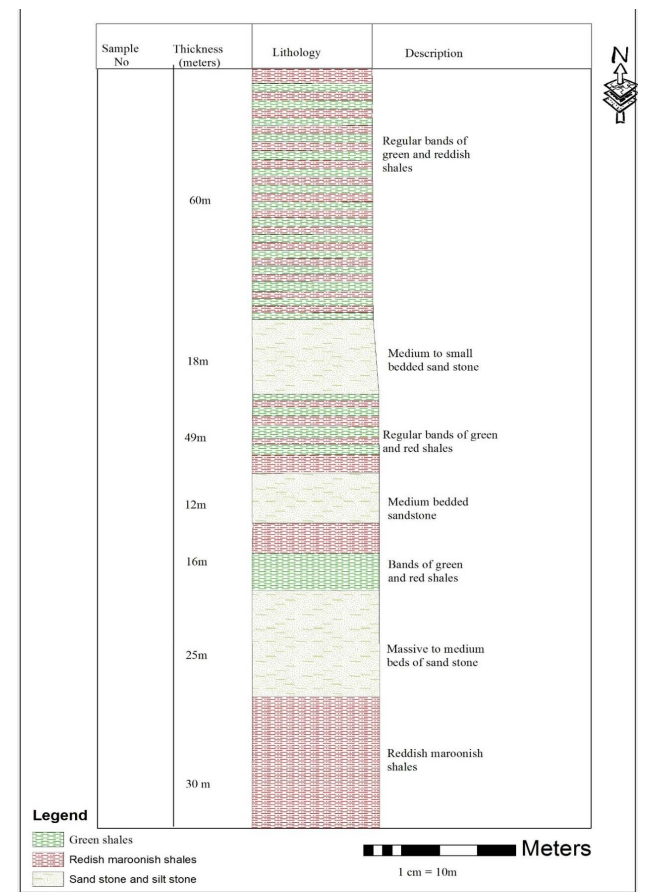

Figure 11: Measured section of Kuldana Formation in Kalamula, Kahuta area.

The Kuldana Formation records the southward progression of a fluvial deltaic system that introduced red shales and sandstones in the basin. It has a continental fluvial origin and was deposited in a basin at the end of a marine regression by rapidly flowing streams (Abbassi and Mcealory, 1991). The sandstone is reddish, maroon, and greenish grey color and shows fluvial and transitional environments in coastal plains (wells and Gingerich, 1987). Reddish maroonish color is due to the presence of hematite while green color indicates chlorite in the sandstone. It is found near the base. The sandstone is embedded at different levels. The sandstone is gray, thin to medium bedded, crossbedded, fine to medium grained and often grade into siltstone. These sandstones contain fragments of quartzite, sandstone, dolomite and limestone. The red color of the clays of the formation is result of oxidation. The Kuldana Formation with abundant clays indicates a condition of standing water in the immediate areas and high local environmental diversity with nearness to sea. The purple clays indicate a relatively high water table (Wells, 1983).

Based on the above discussion it is concluded that Middle Eocene age, Kuldana Formation deposited under transitional environment. This indicates the closing of the ocean and strengthening the argument of the southward shift of the paleogeographic setting and the development of the Hazara- Kashmir foreland basin which marks the end of the Paleogene deposition in the area. The Middle Eocene is the time of main Himalayan collision in northern Pakistan and the formation of Hazara-Kashmir foreland basin (Baig, 1991)

During Eocene, when regression of sea starts Kuldana Formation was deposited. Water transgress towards the south and under shallow marine to transitional environment Kuldana Formation was deposited. Detritus comes from south eastern side was accumulated in the basin. However, the detritus was also supplied from adjacent uplifted area. In lagoonal or calm water condition shales of Kuldana Formation are deposited. Green color of sandstone and shales (Fig. 11) indicates reducing environment under water condition while reddish maroonish sandstone and shales shows oxidizing conditions. The regular intervals of oxidizing and reducing conditions throughout the formation indicated flushing of water conditions on transitional environment during the middle Eocene.

\section{Discussion}

In Paleocene sea water transgression occurred on the western and northwestern margins of the Indian plate (Shah, 2009). However, lower and middle Eocene was a time when most of the north western part of Indian plate was submerged under Epicontinental Sea (Shah, 2009). The Kuldana Formation of middle Eocene shows a faulted contact with Patala Formation (Fig. 2)

The Kuldana Formation is dominantly composed of shales. Shales are green and reddish which are interbedded in a regular pattern. XRD 
analysis of shales showed that the green color of shales is due to presence of chlorite in the rock samples. It also indicates reducing environment. Reddish maroon color of the shales indicates presence of hematite material in the rock samples. XRD analysis of shales showed that shales are highly argillaceous (Fig. 10).

The sandstone exhibits greenish gray to reddish maroon color. Sandstone is medium bedded and occur near the base of the formation. Sandstone is medium to fine grained, hard and compacted. Petrographic studies showed that sandstone is poorly sorted, mineralogicaly immature and classified as wackestone.

\section{Conclusion}

The conclusion drawn on the basis of field and petrographical studies is as follows:

The study area is present in Kahuta area which lies on the Eastern limb of Hazara Kashmir Syntaxis in the Lesser Himalayas. Eocene Kuldana Formation is exposed in Kalamula and Khursheedabad area. The lower contact of Kuldana Formation is faulted with Patala Formation. The upper contact of Kuldana Formation is also faulted with Kailar formation.

2 On the basis of mineralogical composition the sandstone of Kuldana Formation is classified as Greywacke. The sandstone is minerologically immature as it contains low proportion of quartz and very high abundance of rock fragments and matrix. Monocrystalline quartz is more abundant than the polycrystalline quartz while nonundulose quartz is more common than the undulose quartz grains. The angular to sub angular quartz grains indicates short distance of transportation from the source. Plagioclase feldspar albite is found in the sandstone of Kuldana Formation. Alteration of feldspar grains into sericite is commonly recognized.

Rock fragments of igneous, sedimentary and volcanics are abundant in the rock. The sedimentary rocks, fragments are of sandstone, siltstone, dolomite and limestone. The metamorphic rock, fragments are of slates and schist are common while clasts of basalt were recognized in volcanic fragments. The igneous rock fragments are of basalt common in the rocks.

$4 \quad$ Cementing material is dominantly of calcite and hematite while in some samples chlorite is also reported as cement. Accessory minerals tourmaline, zircon, garnet, muscovite, epidote, sphene and apatite were found in the sandstone.

5 Presence of calcite cement shows diagenetic changes. Alteration of biotite into muscovite and chlorite mark the early stage of diagenesis. In few samples sutured and concavo convex contacts of grains also indicate diagenetic changes. The modal mineralogical data plotted on provenance discrimination diagram indicate the provenance is recycled orogeny. The low percentage of quartz and abundance of rock fragments and matrix indicates its transitional depositional environment.

Shales are argillaceous in Kuldana Formation. Bands of green and red shales are dominant in Kuldana formation. Green color of shales is due to high percentage of chlorite present in them while presence of red color is due to hematite abundance in it.

\section{Acknowledgement}

The authors are thankful to Assistant Professor Iqbal Siddiqui, Director Institute of Geology, University of Azad Jammu and Kashmir Muzaffarabad for providing the necessary facilities to carry out the research work. We are thankful to Dr. Rana Asif, Deputy Director Geoscience Laboratory Islamabad, for providing facilities in preparation of thin sections and X-ray diffraction analysis.

\section{References}

[1] Abbasi, I. A., Mcelroy, R., (1991). Thrust Kinematics of the Kohat Plateau Trans-Indus Salt Range Pakistan. Journal of structural Geology, 13:319-327

[2] Ashraf, M., Chaudhry, M. N., (1980). The volcanic rocks of Poonch District Azad Kashmir. Proc Intern Commit Geodynamics Grp 6 Mtg
Peshawar, Special Issue University of Peshawar, Bulletin of Geology, 13:121-128.

[3] Ashraf, M., Chaudhry, M. N., (1984). Petrology of Lower Siwalik rocks of Poonch area. Kashmir Journal of Geology, 2:1-10

[4] Ashraf, M., Khan, M. S., (1993). Petrology and Geochemistry of Panjal Volcanics in Poonch, Muzaffarabad and Kaghan Valley. Project PSF/AJK-Earth/ (33) Final Report, Institute of Geology, UAJ\&K Muzaffarabad. (Unpublished Report), 1-136.

[5] Baig, M. S., Lawrence, R. D., (1987). Precambrian to Early Paleozoic Orogenesis in the Himalaya. Kashmir. Journal of Geology, 5: $1-22$.

[6 Baig, M. S., (1991) Geochronology of Pre-Himalayan and Himalayan tectonic events, Northwest Himalaya, Pakistan. Kashmir Journal of Geology, 8 and 9:197-198

[7] Blatt, H., Tracy, R. (1996). Petrology, Igneous, Sedimentary and Metamorphic. 2nd end., W. H. Freeman Pub. New York, 497 pp.

[8] Bossart, P., Gingerich, D., Greco, A., Ottiger, R., Ramsay., J. G., (1988). The tectonic structure of the Hazara Kashmir Syntaxis southern Himalaya, Pakistan. Tectonics, 7: 273- 297.

[9] Bossart, P., Ottiger, R., (1989). Rocks of the Murree Formation in northern Pakistan: Indicators of a descending foreland basin of late Paleocene to middle Eocene age. Eclogae Geologicae Helvetiae, 82(1): 133-165.

[10] Bossart, P., Ottiger, R., Heller, F., (1989). Paleomagnetism in the Hazara-Kashmir syntaxis NE Pakistan. Eclogae Geologicae Helvetiae ,82:585-601

[11] Calkins, J. A., Offield, T. W., Ali, S. T., (1969). Geology and mineral resources of southernHazara District, West Pakistan, and parts of western Azad Kashmir. U.S. Geological Survey Professional Report (IR) PK. 43-92.

[12] Calkins, J. A., Offield, T. W., Abullah, S. K. M., Ali, S. T., (1975) Geology of the southern Himalaya in Hazara Pakistan and adjacent areas. U.S Geological Survey Professionsl Paper 716-G, 29.

[13] Chaudhry, M. N., Ashraf, M., (1980). The volcanic rocks of Poonch district, Azad Kashmir. Special Issue Geology Bulletin University of Peshawar, 13: 121-128.

[14] Chaudhry, M. N., Ashraf, M., (1984). Geology, petrology and spectrochemistry of Gondwana rocks of Poonch district, Azad Kashmir. Kashmir Journal of Geology, 2: 11-18.

[15] Cotter, G. D. P., (1933). Geology of part of Attock district west of longitude 72 degree 45 minutes E., Geological Survey of India. Memoirs, 55(2): 63-161.

[16] Davies, L. M., Pinfold, E. S., (1937). The Eocene beds of the Punjab salt range. Geological, Survey of India. Palaeontolo. Indica, Memoirs, 24: 1-79.

[17] Dapples, E. C., (1979) Diagenesis of sandstone in Larsen G and Chilingar GV (Eds.) Development in Sedimentology, Els Publ Co Amsterdam, pp 31-97

[18] Dewey JF, Cande S, Pitman WC (1989) Tectonic evolution of the India Eurasia collision zone. Eclogae Geologicae Helvetiae, pp 717734

[19] Dickinson, W. R., Beard, L. S., Brakenridge, G. R., Erjavek, J. L., Ferguson, R. C., Inman, K. F., Knepp, R. A., Lindberg, F. A., Ryberg, P. T., (1983). Provenance of North American Phanerozoic sandstones in relation to tectonic setting. Geological Society of America, Bulletin, 94:222-235

[20] Eames, 1952. A contribution to the study of Eocene in the Western Pakistan and Western India, Part A, the Geology of standard sections in the western Punjab and in the Kohat District. Journal Geology Society London. 107: 159-172.

[21] Gansser, A., (1964) Geology of Himalayas. Inter-Science Publications John Willey and Sons London, pp 189. 
[22] Ghazanfar, M., Chaudhry, M. N., Zaka, K. J., Baig, M. S., (1986). The geology and structure of Balakot area, District Mansehra, Pakistan. Geology Bulletin Punjab University, 2(1): 30-49.

[23] Gingerich, P. D., Jennifer, A., Kitchell, Gerald, R., Smith, (1987). Lower Vertebrates from the Early-Middle Eocene Kuldana Formation of Kohat Pakistan. 27(7): 15 1-193.

[24] Greco, A., (1989). Tectonic and metamorphism of the western Himalayan Syntaxis area (Azad Kashmir NE Pakistan). A dissertation submitted to the swiss Federal institute of Technology, Zurich. 1-193. Gumbel VCW (1888) Grundzuge der Geol Kassel. Fischer, pp 1144.

[25] Heim, A., Gansser, A., (1939). Central Himalaya, Geological observations of the Swiss expendition. 1936. Memoirs Society of Helvetiae, Science National., 73: 245. :

[26] Kazmi, A. H., Jan, M. Q., (1997). Geology and tectonics of Pakistan, pp 67-84

[27] Khan, M. S., (1994). Petrology and geochemistry of the Panjal volcanics in the Ajk and Kaghanareas, the NW Himalayas, Pakistan. Unpublished Ph.D thesis Punjab University, Lahore Pakistan, pp 233

[28] Latif, M. A., (1970). Explanatory notes on the geology of southeastern Hazara to accompany the revised Geological map. Wein J. p. Geol., B.A., 15: 5-20.

[29] Latif, M. A., (1974). A Cambrian age for the Abbottabad Group of Hazara, Pakistan. Geology Bulletin Punjab University, 10: $1-20$.

[30] Lydekker, R., (1876). Notes on the Geology of Kashmir, Kishtwar and Panjal. Indian.Geological Survey, II: 30-64.

[31] Middlemiss, C. S., (1896). The geology of Hazara and Black mountains. Geological Survey of India, Memoirs, 26: 302.

[32] Middlemiss, C. S., (1910). A revision of the Silurian-Trias sequence in Kashmir. Geological Survey of India. Memoirs, 26: 302.

[33] Najman, Y., Garzanti, E., (2000). Reconstructing early Himalayan tectonic evolution and paleogeography from Tertiary foreland basin sedimentary rocks, northern India. Geological Society of America, Bulletin, 112:435-449

[34] Najman, Y., Johnson, C., White, N. M., Oliver, G., (2005). Evolution of the Himalayan foreland basin, NW India, Basin Research, $16: 1-24$

[35] Ottiger, R., (1986). Einige Aspekte der Geologic der HazaraKashmir Syntaxis (Pakistan). Dissertation, ETH Nr., 8083, Zurich.

[36] Pecher, A., (1989). The metamorphism in the central Himalaya. Metamorphic Geology Journal, 7: 31-41.

[37] Pilgrim, (1910). Notices of new mammalian genera and species from territories of India, Geological Survey of India. Record, 40 (1): 63-71.

[38] Pinfold, E. S., (1918). Notes on structure and stratigraphy in the NW. Punjab. Geological Survey of India. Record, 48(3): 137-160.

[39] Reed, J. S., Eriksson, K. A., Kowalewski, M., (2004). Climatic, Depositional and Burial controls on diagenesis of Appalachian Carboniferous Sandstones: Qualitative and Quantitative methods. Sedimentary Geology, 176:225-246

[40] Rustam, M. K., Ali, M., (1994). Preliminary Gravity Model of Western Himalayas in northern Pakistan. Kashmir Journal of Geology, $11 \& 12: 59-65$.

[41] Selley, R. C., (1982). An Introduction to Sedimentology. Academic Press Inc (London) LTD pp 408

[42] Shah, S. M. I., (2009). Stratigraphy of Pakistan. Geological Survey of Pakistan, Memoirs, 22:1-381
[43] Valdiya, K. S., (1980). Geology of the Kumaon, Lesser Himalaya. Wadia Institute of Himalaya. Dehra Dun, India. 291.

[44] Waagen, W., Wynne, A. B., (1872). The geology of Mount Sirban in the upper Punjab. Geological Survey of India. Memoirs., 9: 331-350.

[45] Wadia, D. N., (1928). Geology of Poonch state and adjacent portion of Punjab. Geological Survey of India, Memoirs, 51: 185-370.

[46] Wadia, D. N., (1931). The syntaxis of the North West Himalaya its rocks, tectonics and Orogeny. Record Geological Survey of India, 65: $1-220$

[47] Wadia, D. N., (1934). The Cambrian Trias-sequence of Northwest Kashmir, Geological Survey of India, Record, 68, 2: 121-176.

[48] Wadia, D. N., (1957). Geology of India. Macmillan and Co., London, 3rd ed, 531.

[49] Wynne, A. B., (1873). Notes from a progress report on the geology of parts of the upper Punjab. Geological survey of India. Record, $6(3): 59-64$.

[50] Wynne, A. B., (1874). Notes on the geology of the neighborhood of Mari hills station in Punjab. Geological Survey of India, Record, 7(2): 107-132.

[51] Wells, N. A., (1983). Carbonate deposition, Physical laminology and environmentally controlled chert formation in Paleocene-Eocene Lake Flagstaff central Utah. Sedimentary Geology, $35: 263-296$

[52] Wells, N. A., Gingerich, P. D., (1987). Paleoenvironmental interpretation of Paleogene strata near Kotli Azad Kashmir Northeastern Pakistan. Kashmir Journal of Geology, 5:23-42.

[53] Yin. A. 2006. Cenozoic tectonic evolution of the Himalayan orogeny as constrained by along-strike variation of structural geometry, exhumation history, and foreland sedimentation. Journal of EarthScience Reviews, 76: 13-14.

Table 2: Showing modal analysis of sandstone.

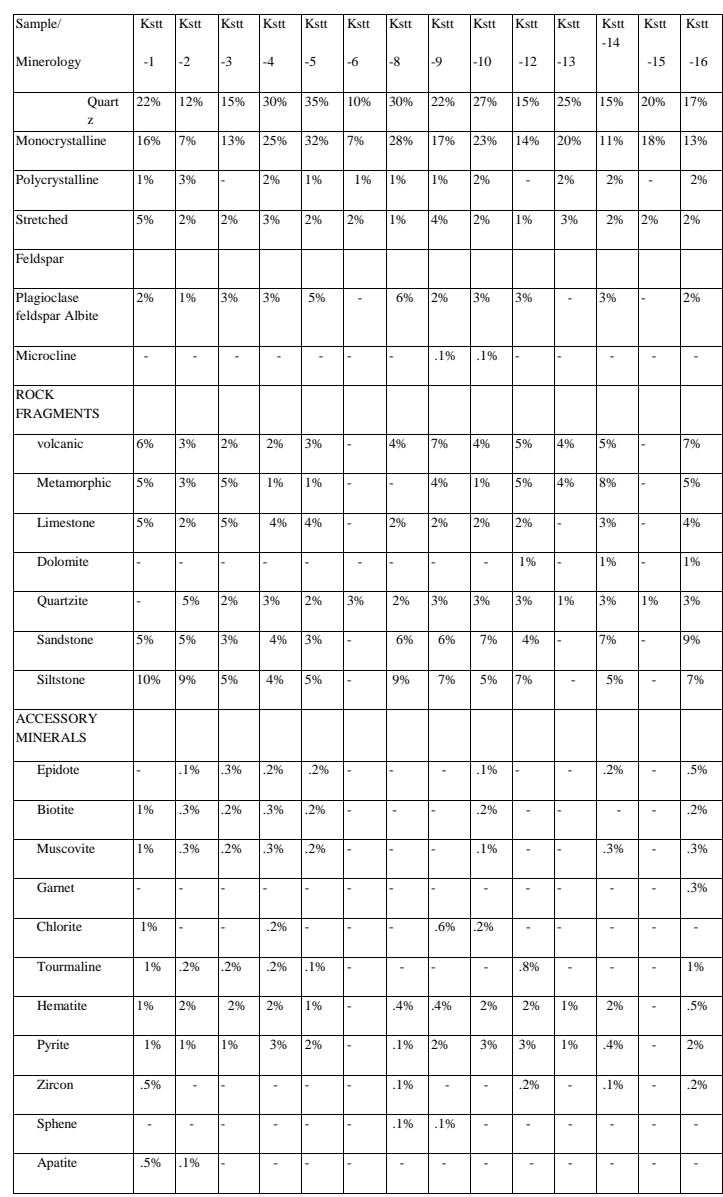




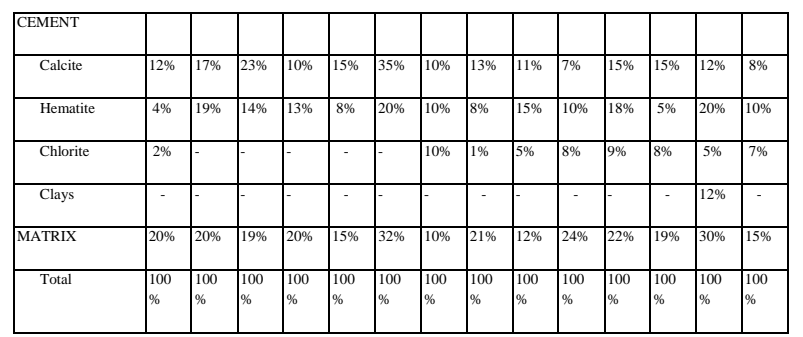

Table 3:Showing recalculated values of QFL in Kuldana sandstone samples.

\begin{tabular}{|c|c|c|c|c|c|c|c|c|c|c|c|}
\hline $\begin{array}{c}\text { Section } \\
\text { Kalamula }\end{array}$ & $\begin{array}{c}\text { Kstt } \\
-1\end{array}$ & Kstt & Kstt & $\begin{array}{c}\text { Kstt } \\
-4\end{array}$ & Kstt & Kstt-8 & Kstt-9 & $\begin{array}{l}\text { Kstt- } \\
10\end{array}$ & $\begin{array}{l}\text { Kstt- } \\
12\end{array}$ & $\begin{array}{l}\text { Kstt- } \\
14\end{array}$ & $\begin{array}{l}\text { Kstt- } \\
16\end{array}$ \\
\hline QFL & (\%) & (\%) & (\%) & (\%) & (\%) & (\%) & (\%) & (\%) & (\%) & (\%) & (\%) \\
\hline Quartz & 40 & 34 & 39 & 59 & 62 & 51 & 43 & 51 & 37 & 31 & 32 \\
\hline Feldspar & 4 & 3 & 8 & 6 & 9 & 10 & 4 & 6 & 7 & 8 & 4 \\
\hline $\begin{array}{l}\text { Rock } \\
\text { Fragments }\end{array}$ & 56 & 63 & 53 & 35 & 29 & 39 & 53 & 43 & 56 & 61 & 64 \\
\hline \multirow{2}{*}{\multicolumn{12}{|c|}{ Accessory }} \\
\hline & & & & & & & & & & & \\
\hline Epidote & - & .1 & .3 & .2 & .2 & - & - & .1 & - & .2 & .5 \\
\hline Biotite & 1 & .3 & .2 & .3 & .2 & - & - & .2 & - & - & .2 \\
\hline Muscovite & 1 & .3 & .2 & .3 & .2 & - & - & .1 & - & .3 & .3 \\
\hline Garnet & - & - & - & - & - & - & - & - & - & - & .3 \\
\hline Chlorite & 1 & - & - & .2 & - & - & .6 & .2 & - & - & - \\
\hline Tourmaline & 1 & .2 & .2 & .2 & .1 & - & - & - & .8 & - & 1 \\
\hline Hematite & 1 & 2 & 2 & 2 & 1 & .4 & .4 & 2 & 2 & 2 & .5 \\
\hline Pyrite & 1 & 1 & 1 & 3 & 2 & .1 & 2 & 3 & 3 & .4 & 2 \\
\hline Zircon & .5 & - & - & - & - & .1 & - & - & .2 & .1 & .2 \\
\hline Sphene & & & - & & - & .1 & .1 & - & - & - & \\
\hline Apatite & .5 & .1 & - & - & - & - & - & - & - & - & - \\
\hline
\end{tabular}

